\title{
How a Public Relations Crisis Led to the Development of a Partnership Between Academics and Student Affairs to Enhance Student Success
}

Steven M. Smith, Enrollment Services and Department of Psychology, Saint Mary's University

Tom J. Brophy, Student Affairs and Services, Saint Mary's University

Adam L. Daniels, Student Affairs and Services, Saint Mary's University

In 2013, a public relations crisis led a mid-size university to reconsider the concept of student success on campus. Collaborations between Academic and Student Affairs leaders have resulted in important changes at the university. The university developed increased ability to support student success by investing in staff positions, exploring best practices to increase student success and retention, and implementing several initiatives including a first-year seminar pilot. Relying on data from national surveys, areas for improvement were identified. Underscoring all of these activities was a focus on student development theory, an increased understanding of institutional data, and a commitment to a comprehensive pan-institutional approach. Because the university has a lower than desired graduation rate (55\%), several action teams were created to oversee various goals related to communications, year-long orientation experiences, and an academic anchor. Ultimately, this work has now reached the stage where a strategic enrollment management plan is under creation.

Keywords: student success, first-year experience, retention 
Although crises can be challenging and difficult to live through, they can sometimes lead to a new and better status quo. The purpose of this paper is to provide an example of such an occurrence. We will describe the experience of one university which went through a major public relations crisis, and how the university community responded in terms of a fundamental rethinking of how to approach student success, forging a partnership between the academic and student affairs arms of the university. We will begin by providing an overview of the university context. Next, we will provide a summary of student development theory, explain the situation the university found itself in, and explain how we responded while considering student development theory. Finally, we will provide an overview of where we are now, and the current directions of our student success program.

\section{The University Context}

The university in question is on the east coast of Canada, and has approximately 6700 total students, 32\% of whom come from over 100 countries across the globe. Most domestic students come from the relatively local catchment area, within $100 \mathrm{~km}$ of the university. Overall, gender identification is equally (rounding to 50\%:50\%) split between those identifying as male or female, with less than $1 \%$ selecting "other gender identity," with $90 \%$ of students doing undergraduate studies in Arts and Social Science, Business, or Science programs. The vast majority (86\%) of students attend the university full-time and most (67\%) of students arrive at the university direct from high school (though we do have a significant number of students who transfer from colleges or other universities).

There is a recognition among the academic leadership that our overall 7 -year graduation rate of approximately $55 \%$ is significantly lower than we would like. Further, we know that we lose over $20 \%$ of our entering class within the first year of their enrolling at the university. In order to address these issues, the university has invested significantly in internal and external surveys in an attempt to identify factors influencing student success. 
The 2017 National Survey on Student Engagement (NSSE) has demonstrated that our university's new students spend an average of 11.9 hours a week on academic preparation versus 15.1 hours at other Atlantic Canadian Universities. Senior students spend 13.4 hours a week on academic preparation versus 16.3 hours. We are $12 \%$ lower than our peers on students feeling challenged to do their best work. For senior students, we are $16 \%$ lower in providing internships, field experiences, co-op, etc. Finally, $77 \%$ of new students at the university rate their experience as good or excellent vs. 83\% at other universities. All of these findings highlight specific areas where we could improve. On the positive side, we are rated 10\% (New) and 18\% (Senior) higher than other Atlantic Canadian universities on encouraging more interactions with students from different cultures. For senior students, we are 14\% higher than other institutions in helping students manage non-academic responsibilities; and $85 \%$ of senior students at the university rate their experience as good or excellent vs. an average of $83 \%$ for Atlantic Canadian universities.

The 2016 Canadian University Student Consortium (CUSC) provides additional important findings. Seventy-one percent of new students agree or strongly agree that they feel that they belong in our university versus $85 \%$ for universities across Canada. Eighty-nine percent of our new students said they were satisfied with their decision to attend the university vs. $92 \%$ for all of Canada. Nonetheless, $79 \%$ of our students indicated receiving a financial award vs. 58\% nationally - something to be proud of considering student finances are a prime reason students leave university (Canadian University Survey Consortium, 2016).

Perhaps not surprisingly, the CUSC survey further reported that the top five reasons for students to attend this university were to prepare for a career, to enhance their job prospects, to earn more money, to make a positive difference, and to satisfy their intellect. Students chose the university specifically because it had the program they wanted, was cost effective, allowed them to (either) live close to home or away from home, and offered scholarships. Perhaps most importantly, the CUSC Survey found that $60 \%$ of new students attended our Welcome Week programming, and of those who did, 92\% felt welcomed, $84 \%$ were very 
or somewhat satisfied that it provided with info about campus life and services, 91\% were very or somewhat satisfied that it built confidence, and $82 \%$ were very or somewhat satisfied that it helped students transition to university.

\section{The Public Relations Crisis}

\section{3: What Happened?}

In early September 2013, during our annual orientation week (as it was then called) students were participating in a group on-field teambuilding event. During the event, as happens at many institutions, a mix of male and female student leaders led new students in the singing of a song that came to be referred to as the "rape chant." The song was deeply misogynistic and advocated non-consensual underage sex. Although claims were made that the song had been sung on campus for at least the last few years, what made this incident different was that it was posted to Twitter. The incident quickly went viral, and caused massive public reaction, garnering local, regional, national, and even international attention, being featured on major news networks like CNN.

\section{The Reaction}

In the wake of the incident, the university immediately issued an apology. The Student Union President and Vice-President who were responsible for Orientation resigned. Perhaps not surprisingly, as the university and student association tried to address what had happened, trust between the two groups was negatively impacted. Quite quickly, there was a realization that positive and significant action was needed. To begin the response, the President created an Action Team to identify what had happened, assess the university culture and processes, and make recommendations for immediate change. Although many actions were taken, a primary focus was to understand that a well-formed Welcome Weeks approach, leading to a year-long orientation process, was needed. In late 2013, a First Year Experience Committee was formed, with an initial focus on student orientation. A year later, revamped and academically driven Welcome Weeks were launched. In 2015, our long-serving President retired, and a new President was hired who 
developed a university strategic plan with student success as a primary component. In 2016, the very long-serving Senior Director of Student Affairs and Services retired and was replaced. From these changes, the new First Year Experience Committee was born. Because this was a completely new approach for the university (many different initiatives had been undertaken, but a comprehensive approach had not before been developed) we were able to start "from scratch" using post-secondary best practice as our common starting point.

\section{Foundations of the Approach: Successful Student Transitions into Post-Secondary Education}

Across North America, data from more than 50 years of research demonstrates the effectiveness of initiatives to improve student transition into, through, and out of university. Core elements to success include a broad perspective on student orientation, effective and targeted communication, and the use of some version of an academic anchor, including a broad array of co-curricular supports. The research shows clearly that consistent, evidence based, and comprehensive programs positively influence student success, retention, satisfaction, and fulfillment (Upcraft et al, 2004).

There have been a multitude of theoretical approaches to supporting student transitions. Typically, these fall into one of three categories: 1) psychosocial theories - which explore the personal and interpersonal aspects of students' lives; 2) cognitive/structural theories - which explore the intellectual growth of students and the ways students bring meaning to their experiences; 3) Typological Theory - which focuses more on individual differences between students which influence how they handle developmental experiences.

For example, Erik Erikson's (1959) Life Span Model (a psychosocial theory) proposes eight stages of development from building trust in infancy to dealing with death in later life. At the age our students arrive, they are struggling with their own identity and the multiple roles they inhabit, as well as developing their relationships and finding meaning in their lives. Sanford (1966) introduced the concept of challenge versus support - that in order for students to be successful, they needed to be 
challenged, but also needed the support to overcome those challenges. He further posited that the supports needed depend on personality, background, and previous life experiences.

Chickering (1969; Chickering \& Reisser, 1993) proposed that there were seven "vectors" students worked through: developing competence (interpersonal, intellectual, physical, and manual); managing emotions (identify and express emotions in a healthy manner); moving through autonomy toward interdependence; developing mature interpersonal relationships; acceptance of differences; establishing identity (with their physical appearance, gender identity and sexual orientation, cultural identity, comfort with roles and lifestyles, sense of self from significant others, self-esteem, personal stability); developing purpose (i.e., clear career goals); and developing integrity (moving from rigid/moralistic/ judgmental thinking to value driven, humanized and respectful of differences).

As the 1960's rolled into the 1980's, cognitive structural perspectives started to gain acceptance (Perry, 1970; Belenkyet al, 1986; Kohlberg, 1976, 1980; Gilligan, 1977, 1982). For example, Perry's theory of cognitive development focused on college students and identified four levels; Dualism, Multiplicity, Relativism, and Commitment to Relativism. Astin's IEO Theory $(1994,2007)$ spoke to the key factors that determine student involvement. Specifically, he argues that inputs (I -- demographic, socioeconomic, past experiences, etc.), environment ( $\mathrm{E}$-- experiences and supports available during college), and outcomes ( 0 -- how the students' beliefs, knowledge, values, attitudes have evolved postgraduation) must all be considered to understand student success.

As a corollary to Astin's theory of involvement, Tinto (1993) developed a theory of student departure. Tinto argued and provided substantial evidence to support the idea that students leave postsecondary because of the quality of their experiences while attending. Students enter with their unique characteristics (cultural, socioeconomic, values, educational motivations, first generation, etc.), and postsecondary environments have unique characteristics. If there is a mismatch between the two, students will leave unless this can be reconciled. Fundamentally, 
this comes down to institutional fit. Tinto further identifies three specific reasons why students leave: academic problems (academic skills, time management, etc.); failure to socially and intellectually integrate in the campus culture; and low levels of commitment to educational goals. Importantly, Tinto and later researchers (e.g., Upcraft et al., 2004) identified how first-year seminars could positively affect these outcomes.

\section{What Leads to Student Success?}

The Association of American Colleges and Universities (AACU) has identified, based on voluminous research conducted by the authors identified above and others, the following "high impact practices" - that is, practices universities can engage in that will improve student success, retention, and graduation rates when applied in the first year. Further, although each practice increases student success, engaging in multiple practices can have a multiplicative effect on retention and graduation rates. Specifically, the AACU found that the following practices lead to increased student engagement and increased student success: a yearlong approach to orientation, common intellectual experiences, learning communities, writing-intensive courses, collaborative assignments and projects, undergraduate research, diversity and global learning, serviceand community-based learning, internships, and capstone courses and projects.

Further, we know that successful students share the following characteristics: They have an early connection to the campus which relates to a sense of belonging to a group and being a valued member of a community. They exhibit social engagement that drives learning, and experience active learning contexts. They have contextualized and personalized academic supports. They have an integration of library resources or writing center supports into their assignments. They have clear and "high enough" expectations. There is active involvement in learning with other students, which is related to high impact practices. 


\section{What did we try to accomplish?}

Given the data provided above and the evidence from developmental theory, it became clear that the way to successfully engage and retain our students to their second year and through graduation requires a studentcentered developmental change approach. This was novel to many on the committee, in the sense that most faculty and staff had little knowledge regarding the nature and attitudes of our student body (data were not freely shared previously), and although there was a general sense that the goal of improving student success was central to our mission, few had the theoretical background knowledge to understand best practices on how to move forward.

The first step was to form a campus-wide committee to begin to tackle this problem. Because there were four pillars formed out of the President's Strategic Plan, a Dean of each of the four Faculties was tasked with leading one initiative. The Dean of Science, who had launched a number of outreach and engagement activities in the Faculty of Science, was tasked with leading the First Year Experience (FYE) Committee. Shortly after the Committee was formed, the new Senior Director of Student Affairs and Services started; he advocated for clear involvement of the Department in the initiative. Subsequently, the Dean of Science and the Senior Director of Student Affairs and Services became co-Chairs of the Committee. In an effort to break down silos, and to ensure there were both people on the committee who could make decisions (senior leadership) and people who "worked in the trenches" who could get the work done, the committee was necessarily large and diverse. In addition to the co-chairs, the committee included Associate Deans from each Faculty, the Associate Vice-President of Enrolment Management \& Registrar, the University Librarian, members from Student Affairs and Services (including staff with foci in mental health, transitions, and career services), faculty members from each Faculty, student advisors from each Faculty, and multiple student government representatives. 


\section{What was our mandate?}

In the first year of our existence, the FYE Committee had the mandate to review the existing state of student success, identify barriers, improve student success through best practice-based academic and co-curricular programs, work across Faculties and across all aspects of the University to improve student experience in the first year, and develop a budget model for go-forward funding of projects. Initially the University allocated $\$ 100 \mathrm{k}$ to manage all four of the Strategic Plan committees. This may seem like a small amount of money, but it allowed committees to fund pilot initiatives to serve as "proof of concept" for programs in the future.

After much discussion, the committee came to the conclusion that in order to be successful, students needed:

- an earlier, stronger, and more satisfactory connection with the university

- opportunities for personal development (social, emotional, ethical)

- enhanced social integration into campus community

- improved coping skills

- respect for different opinions and value for diversity

- increased persistence

- increased rate of use of academic supports (including library use)

- increased interest and attendance at coordinated campus events

- earlier expressions of major declaration

- opportunities for academic skill development

- improved information literacy

- increased vocabulary

- development of critical thinking skills leading to improved academic performance

\section{What Have We Been Doing?}

Our first goal was to understand the university's "lay of the land" in terms of people's understandings for student success and our typical demographic. This highlighted to us the need to ensure we had consistent data about our students. Thus, the co-chairs made efforts to present data about students during meetings. Quite literally, when we announced 
our graduation rates, there were audible gasps. Although people knew not every student graduates, there was shock about the extent to which students leave. This is perhaps not surprising in that both faculty and staff are much more likely to engage with students who stay, and therefore those are the example that are "available" in memory (Tversky \& Kahneman, 1973; Schwartz et al, 1991).

Our second task was to develop Action Teams (subcommittees) to address specific goals we had set. Thus our first teams were to develop a yearlong process for orientation to the university - this group looked at methods to shift the mass amount of information given to students during Welcome Weeks to a situation where they were given the information they needed, when they needed it, across the first year. Another Action Team focused on communications - with the aim to review and coordinate communications to incoming and first-year students (for example, we had 17 different units on campus communicating with students prior to their arrival; there was no coordination across those units).

Next, we created an Action Team to develop a pilot of a first-year seminar program. Though there are many ways in which this can be done, our focus was to create a program which would engage all firstyear students, and where the co-curricular components (e.g., information literacy, time management, campus safety, study skills) were fully integrated into for-credit courses taught by faculty. A core element was to develop faculty champions and have systematic professional development for those faculty (and any others) who wanted to integrate student success initiatives into their courses. As such, we had teams attend multiple FYE conferences and also held annual retreats to explore high impact practices (Kuh, 2008) within academic courses.

After 5 years of work, we have revised and enhanced Welcome Weeks; moved to a system where we develop and plan based on institutional data and predictive analytics; developed pre-orientation videos to inform students about aspects of student transition; and developed and participated in surveys including NSSE, CUSC, exit interviews, and an accept/decline survey so we can understand why students don't come to the university. We have hired a first-ever Student Communications Officer, and have reviewed and enhanced the university website, creating 
a New Student Resources page which breaks down the normal barriers of department-by-department messaging. We have launched first-year student research grants which allow faculty to hire promising students full-time into their labs for the summer after their first year at the university.

Importantly, following recommended best practice, we completed a formal review of academic regulations, with a focus on removing barriers to student success. This resulted in a change of probation policies so that we can intervene with students before they get to a point where suspension and dismissal are inevitable. We continue to work with NSSE but have now launched the use of the Beginning College Survey of Student Engagement (BCSSE) to allow us to more effectively use predictive analytics to plan based on institutional data.

One of our most ambitious undertakings was to launch a firstyear seminar pilot program focusing on the implementation of high impact practices within first-year academic courses. Importantly, we targeted key required first-year courses within Business and Science with high enrollments. Although still at the pilot stage, via experimental methodology we have demonstrated significant improvements in student performance (Smith \& Brophy, 2018). The program is expanding as our faculty champions speak to the positive impact the programs are having on their students.

Also at the pilot stage, we have launched an early alert program. This year that program provided "coverage" to 2000 students, with over 200 alerts and direct support for approximately 50 students (the remainder did not respond to our communications). There were a broad range of alerts reported, including missed classes, trouble with or missed assignments, behavioral issues or concerns, as well positive reports such as excellent performance. This initiative has been invaluable to guide us in what structures and IT platforms are needed to grow and improve the responsiveness of the program. 


\section{What's to Come?}

With several years of successful projects under our belt, we are now moving to tackle some of the "stickier" elements around student success. We are hoping to develop a more robust peer mentorship model that moves away from separate programs under differing departments into one cohesive program that touches each student. We are also looking to enhance our resources substantially and move to mandatory advising for new students. We are establishing a more intentional Early Alert Program. We are continuing to expand and enhance the FYE seminar pilot and are aiming to have $70 \%$ of new students involved in the program. We are also looking to develop "involvement advising" and build more comprehensive supports for our commuter students (who represent over $80 \%$ of our students). In addition, we have begun to develop Living Learning Communities in student housing.

Our success across silos and across topics has led to the endorsement from university executive management and the Board that we should develop a Strategic Enrolment Management plan that covers the gamut of student experience from their first contact with a recruiter to their becoming a successful and contributing university alum.

\section{Lessons Learned}

Perhaps not surprisingly, we have learned a great deal as the process of developing a First-Year Experience program has progressed. First, it is vital to understand your students - you must not only have data, but those data must be seen to be accurate. It is critical to have a data professional on the committee and at the university (also a new development for our university in 2019). Further, new data must be collected (via surveys, etc.) to ensure the most accurate representation of students and their needs. Second, it is important to understand the political landscape of the university, both internal and external. The leaders, and the committees, must comprehend the existing silos and take the time to break down barriers to change.

When engaging in such a program, committee structures are necessary, but you also must be wary of "death by committee." Reframing 
groups as action teams with measurable and time-limited outcomes encourages groups to develop subordinate goals and focus on what can be accomplished rather than what stands in the way. As such, executive mandates to improve and change are necessary in order to get work done. If any one group or individual is permitted to stand in the way, the tasks can screech to a halt. That said, from a change management perspective, it is important to understand and respect existing processes. Teams must manage the pace of change, and start by securing the support of change agents.

In addition to executive support, one final feature that is absolutely necessary is financial support. It is relatively easy to make the financial argument as to why we should encourage student success: more success $=$ more students in courses $=$ more revenue. However, if committees are expected to act and change based on good will, this is a recipe for failure. Even small amounts of money to begin with (as noted above we started with $\$ 100,000$ for four strategic committees) can provide units and teams with the motivation and resources to start getting things done and demonstrate effectiveness, which encourages further investment.

\section{Conclusion}

What is clear from the decades of research on student success in North America is that student success does not arise by chance - it is not simply the result of good intentions or the by-product of a small number of well-intended but limited approaches offered by diverse units across a university. An effective first-year experience is a structured, intentional, and systematic course of action that coordinates the work of many people, programs, and offices across and throughout the campus promoting student success. Providing students access to university without the requisite support does not provide meaningful opportunities to succeed. An effective approach must be multifaceted, integrated, and comprehensive.

The wonderful thing about focusing on student success is that it is not only the "right" thing to do for our students, but it is also the "smart" thing to do from a financial perspective. Students benefit by finishing their studies in a way that enhances their self-efficacy, and allows them to 
become higher income earners (Statistics Canada, 2017); aside from the obvious benefit of greater tuition revenue, universities benefit by having a broader array of successful alum that they can brag about and rely on to support their university in future years; and society benefits by have a broader and more diverse group of individuals who can contribute to the welfare of the communities in which they live. 


\section{References}

Astin, A. (1994). Assessment for excellence: The philosophy and practice of assessment and evaluation in higher education. The Oryx Press.

Astin, A. (2007). Mindworks: Becoming More Conscious in an Unconscious World. Information Age Publishing.

Belenky, M., Clinchy, B., Goldberger, N., \& Tarule, J. (1986). Women's Ways of Knowing. Basic Books.

Canadian University Survey Consortium. (2016). 2016 First-Year University Student Survey. Ottawa: Prairie Research Associates.

Chickering, A. (1969). Education and Identity. Jossey-Bass.

Chickering, A., \& Reisser, L. (1993). Education and Identity 2nd Edition. Jossey-Bass.

Erikson, E. (1959). Identity and the Life Cycle. International University Press.

Gilligan, C. (1977). In a Different Voice: Women's Conceptions of Self and of Morality. Harvard Education Review.

Gilligan, C. (1982). In a Different Voice: Psychological Theory and Women's Development. Harvard University Press.

Kohlberg, L. (1976). Moral stages and moralization: The cognitivedevelopmental. Holt, Rinehart and Winston.

Kuh, G. (2008). High-Impact Educational Practices: What They Are, Who Has Access to Them, and Why They Matter. Association of Amercan Colleges \& Universities.

Perry, W. (1970). Forms of Intellectual and Ethical Development in the College Years: A Scheme. Holt, Rinehart, and Winston.

Sanford, N. (1966). Self and Society: Social Change and Individual Development. Atherton.

Schwartz, N., Bless, H., Strack, F., Klumpp, G., \& Simons, A. (1991). Ease of retrieval as information: Another look at the availability heuristic. Journal of Personality and Social Psychology, 195-202.

Statistics Canada. (2017). Census in Brief: Does education pay? A comparison of earnings by level of educaton in Canada and its provinces and territories. Government of Canada. 
Tinto, V. (1993). Leaving College: Rethinking the Causes and Cures of Student Attrition 2nd Ediion. University of Chicago Press.

Tversky, A., \& Kahneman, D. (1973). Availability: A Heuristic for Judging Frequency and Probability. Cognitive Psychology, 207-232.

Upcraft, M., Barefoot, B., \& Gardner, J. (2004). Challenging and Supporting the First-Year Student: A Handbook for Improving the First Year of College. Wiley. 